JUNAIDI, AKHMAD ASYARI, ULFA LU'LUILMAKNUN, NILZA HUMAIRA SALSABILA, R Y TYANINGSIH

The Application Two-Way of Analysis Variance with Gender and Years Class

\title{
The Application Two-Way of Analysis of Variance with Gender and Years Class
}

Junaidi $^{* 1}$, Akhmad Asyari ${ }^{2}$, Ulfa Lu'luilmaknun ${ }^{3}$, Nilza Humaira Salsabila ${ }^{4}$, and R Y Tyaningsih ${ }^{5}$

1,3,4,5 Mathematics Education Department, Universitas Mataram, Indonesia

${ }^{2}$ Islamic Education, Universitas Islam Negeri Mataram, Mataram, Indonesia

*junaidi88@unram.ac.id

\begin{abstract}
ABSTRAK
Setiap tahun penerimaan mahasiswa baru dengan berbagai latar belakang menyiratkan bahwa mahasiswa memiliki kemampuan yang berbeda-beda. Perbedaan kemampuan siswa sesuai dengan kebiasaan belajar siswa. Kebiasaan belajar siswa mungkin berbeda jika dilihat dari jenis kelamin dan kelas tahun siswa. Berdasarkan perbedaan kemampuan siswa diperlukan untuk melakukan penelitian untuk menentukan hubungan antara kelas tahun siswa dan jenis kelamin terhadap kebiasaan belajar siswa. Penelitian ini adalah studi ex post facto dengan sampel 203 siswa karena sampel dipilih dengan teknik random sampling sederhana. Berdasarkan analisis analisis statistik varians dari dua jalur yang diperoleh oleh kebiasaan belajar siswa tidak berbeda dalam hal gender ini dapat dilihat dari Fscore $=0,008$ dengan sig $=0,93>0.05$, sementara kebiasaan belajar siswa berbeda jika dilihat dari tahun kelas siswa ini dapat dilihat dari nilai Fscore $=3,537$ dengan sig $=0,008<0,05$. Tes post hoc menunjukkan bahwa siswa selisih semester 10 dengan mahasiswa semester 4 dan semester 2. Selisih mahasiswa semester 2 dengan semester 6 dan semester 8 .
\end{abstract}

Kata kunci: Gender, Kebiasaan Belajar, Tahun Angkatan

\begin{abstract}
Every year the admission of new students with various backgrounds implies that students have different abilities. The difference in student abilities corresponding to student learning habits. Student learning habits maybe different if viewed from the gender and student's years class. Based on differences of student abilities is necessary to conduct research to determine the relationship between student's years class and gender toward student learning habits. This study was an ex post facto study with a sample of 203 students as the sample was selected by simple random sampling technique. Based on analysis of variance statistical analysis of two paths obtained by students' learning habits do not different in terms of gender this can be seen from Fscore $=0.008$ with sig $=0.93>0.05$, while students' learning habits are different if viewed from the year of the student's class this can be seen of the value Fscore $=3.537$ with sig $=0.008<0.05$. Post hoc test indicated that students' $10^{\text {th }}$ semester difference with student $4^{\text {th }}$ semester and $2^{\text {th }}$ semester. Students $2^{\text {th }}$ semester difference with $6^{\text {th }}$ semester and $8^{\text {th }}$ semester.
\end{abstract}

Key words: Gender, Learning Habits, Years Class

Received: 2021-01-26

/ Accepted: 2021-04-14

/ Published: 2021-05-01

\section{Introduction}

During this time instruction is not difference for every student with difference semester. From year-to-year instruction in classroom always not difference. Every year the new student admission with different backgrounds, student must learn in the same way. This is due because no research results suggest that every student with difference semester have difference path to learn or difference learning habit.

Learner's personal characteristics can affect how students learns. Students follow difference paths to learn based on their gender and experience. How students learn everyday will be students learning habits. Students learn experience follow difference student years class. Students in higher education differ in their learning approach and having different learning habits (Urh \& Jereb, 2014). 
Study habit or learning habit contribute significantly in the development of knowledge and perceptual capacities (Pamujo, 2014; Amuda \& Ali, 2018). Study habits tell to students that how much students will learn and how far students want to go (Rabia et al., 2017). Without good study habits, student cannot succeed. How a student his or her studies, greatly determines level of academic achievement. The level of preparations and learning strategies developed and employed consciously by student go a long way to influence their level of academic performance (Ebele \& Olofu, 2017; Purwaningsih, 2018).

Study habit or learning habit improve prediction of academic performance more than any other noncognitive individual difference variable examined to date and should be regarded as one of the third pillar of academic success (Credé \& Kuncel, 2008). Method of study shows that there is a significant relationship to the academic achievement but it does not assist the towards the student's academic performance as it shows a negative and weak relationship (Silverrajoo \& Hassan, 2018). There is a positive relationship of 0.66 between study habits and academic achievement. The results implied that the study habits need a significant attention if we are to improve performance. There was a clear finding that the teachers and students seem not to take effort in developing good study habits (Julius \& Evans, 2015; Amuda \& Ali, 2018).

In this study a two-way variance analysis was used to find out if there were significant differences in student learning habits reviewed from gender and years class. Whether or not the interaction between gender and semester affects learning habits can be known by two-way analysis of variance.

Based on the results of the studies outlined indicates that the Students learning habits are an important factor research needs to be done that examines how student learning habits, do male and female student learning habits differ and whether students learning habits in each semester differ. The results of this research as a basic for lecturers to plan learning for students.

\section{Research Method}

The participants of this study were 203 mathematics education undergraduate students, 40 were men and 163 were women. 36 students were $10^{\text {th }}$ semester, 67 students were $8^{\text {th }}$ semester, 29 students were $6^{\text {th }}$ semester, 17 students were $4^{\text {th }}$ semester, and 54 students were $2^{\text {th }}$ semester. This study was conducted in August 2019. This research is quantitative methods with ex post facto design. Sample were selected by simple random sampling.

The data in this research were obtain through a questionnaire about students mathematical learning habits. The questionnaire consists of 6 question about preparation or Behavioral patterns before learning, 7 question about Attitude toward learning, and 7 question about Behavioral patterns Skills of learning. The questionnaire validated by two expert judgement. Details of the learning habits indicator can be seen in Table 1.

Table 1. Grille of students learning habit

\begin{tabular}{llc}
\hline No. & \multicolumn{1}{c}{ Indicator } & Statement No. \\
\hline 1. & $\begin{array}{l}\text { Patterns of behavior concerning knowledge: } \\
\text { learning readiness and is not related to attitudes. }\end{array}$ & $7,11,13,15,19,20$
\end{tabular}


2. Patterns of behavior concerning attitudes: the tendency of responses to $6,9,10,12,14,16,18$ be carried out in relation to the preparation of learning.

3. Patterns of behavior concerning skills: behavior related to skills in the $1,2,3,4,5,8,17$ management of conduct to be carried out.

Data obtained were analysed with two-way of variance analysis. Analysed based on two perspective. First perspective is gender and the second perspective are year class (semester). The data of mathematical learning habits is interval level, there are cumulative score from each student after pass the questionnaire.

\section{Result and Discussion}

Data obtained from 203 participants who had filled out the questionnaire was descriptively analyzed. Data description of gender can be viewed on the Table 2 and description of year class on the Table 3.

Table 2. Description of gender

\begin{tabular}{clcc}
\hline No & \multicolumn{1}{c}{ Statistic } & Men & Women \\
\hline 1 & Mean & 57,9 & 58,2 \\
2 & Median & 57 & 58 \\
3 & Variance & 81,8 & 58,5 \\
4 & Maximum & 80 & 80 \\
5 & Minimum & 35 & 38 \\
6 & Std.deviation & 9 & 7,6 \\
\hline
\end{tabular}

Table 3. Description of year class(semester)

\begin{tabular}{llccccc}
\hline No & \multicolumn{1}{c}{ Statistic } & $\begin{array}{c}10 \text { years } \\
\text { sclass }\end{array}$ & $\begin{array}{c}8 \text { years } \\
\text { class }\end{array}$ & $\begin{array}{c}6 \text { years } \\
\text { class }\end{array}$ & $\begin{array}{c}4 \text { years } \\
\text { class }\end{array}$ & $\begin{array}{c}2 \text { years } \\
\text { class }\end{array}$ \\
\hline 1 & Mean & 56 & 57 & 57 & 61 & 61 \\
2 & Variance & 61 & 49 & 35,4 & 71 & 78 \\
3 & Maximum & 69 & 76 & 69 & 80 & 80 \\
4 & Minimum & 35 & 39 & 38 & 48 & 41 \\
5 & Std.deviation & 7,8 & 7 & 5,9 & 8,4 & 8,8 \\
\hline
\end{tabular}

Data obatained is analyzed by inferential statistic. There is two assume must be complete before analysed with two way of variances analysed. The first assume is data normality and the second is variances homogeneity. Based on test of normality with SPPS Suggests that data is normal.

Table 4. Test of data normality

\begin{tabular}{ccccc}
\hline & \multicolumn{4}{c}{ Kolmogorov-Smirnov } \\
& GENDER & Statistic & df & \multicolumn{1}{c}{ Sig. } \\
\hline \multirow{2}{*}{ SKORE } & Women & .056 & 163 & $.200^{*}$ \\
& Men & .102 & 40 & $.200^{*}$ \\
\hline
\end{tabular}

Based on Table 4 value of sig. for women and men 0,2 are more than 0,05 so that null hypothesis accepted, it is mean the data is normal.

The second assume is variances homogeneity. Based on test of equality of error variances suggests that variances homogeneity is done.

$34 \mid \begin{aligned} & \text { @2021 by Department of Mathematics Education, UMP, Purwokerto, Indonesia } \\ & \text { p-ISSN 2477-409X, e-ISSN: 2549-9084 and website: http://jurnal nasional.ump.ac.id/index.php/alphamath/ }\end{aligned}$ 
Table 5. Test of equality of error variances

\begin{tabular}{cccc} 
F & df1 & df2 & Sig. \\
\hline 1.768 & 9 & 193 & .077
\end{tabular}

Based on Table 5 sig. value 0,077 is more than 0,05 so that null hypothesis accepted, it is mean the data have equal of variance.

Assume two way of variances analysed is done then analysed with two way of variances analysed suggest that not difference students mathematical learning habits in terms of student years class(semester).

Table 6. Two way of variances analysed

\begin{tabular}{lrrrrr}
\hline Source & $\begin{array}{r}\text { Type III Sum } \\
\text { of Squares }\end{array}$ & df & $\begin{array}{r}\text { Mean } \\
\text { Square }\end{array}$ & F & Sig. \\
\hline Gender & .457 & 1 & .457 & .008 & .930 \\
Semester & 847.810 & 4 & 211.953 & 3.537 & .008 \\
gender * semester & 78.987 & 4 & 19.747 & .330 & .858 \\
\hline
\end{tabular}

Based on Table 6 sig. value 0,930 is more than 0,05 so that null hypothesis is accepted. Null hypothesis accepted means not differences students mathematical learning habits between men and women. More over in term of semester sig. value 0,008 is less than 0,05 so than null hypothesis is Rejected. Null hypothesis rejected means there are differences students mathematical learning habits between students in term of student years class (semester). Students mathematical learning habit in term of interaction gender and semester have Sig. value 0,858 is more than 0,05 . It is means there are no interaction between gender and semester toward students mathematical learning habits.

Students year class (semester) have five categories there are students $10^{\text {th }}$ semester, $8^{\text {th }}$ semester, $6^{\text {th }}$ semester, $4^{\text {th }}$ semester, and student $2^{\text {nd }}$ semester. Post hoc test indicated that students $10^{\text {th }}$ semester difference with student $4^{\text {th }}$ semester and $2^{\text {nd }}$ semester. Students $2^{\text {nd }}$ semester difference with $6^{\text {th }}$ semester and $8^{\text {th }}$ semester.

Table 7. Post hoc tests

\begin{tabular}{llrrr}
\hline & \multicolumn{5}{c}{$\begin{array}{c}\text { Mean Difference } \\
(\mathrm{I}) \mathrm{J})\end{array}$} & Std. Error & Sig. \\
\hline 10 & 8 & -1.5875 & 1.59973 & .322 \\
& 6 & -1.4588 & 1.93163 & .451 \\
& 4 & $-5.2337^{*}$ & 2.27813 & .023
\end{tabular}


JUNAIDI, AKHMAD ASYARI, ULFA LU'LUILMAKNUN, NILZA HUMAIRA SALSABILA, R Y TYANINGSIH

The Application Two-Way of Analysis Variance with Gender and Years Class

\begin{tabular}{|c|c|c|c|c|}
\hline & 2 & $-5.8056^{*}$ & 1.66567 & .001 \\
\hline \multirow[t]{4}{*}{8} & 10 & 1.5875 & 1.59973 & .322 \\
\hline & 6 & .1287 & 1.72074 & .940 \\
\hline & 4 & -3.6462 & 2.10230 & .084 \\
\hline & 2 & $-4.2181^{*}$ & 1.41571 & .003 \\
\hline \multirow[t]{4}{*}{6} & 10 & 1.4588 & 1.93163 & .451 \\
\hline & 8 & -.1287 & 1.72074 & .940 \\
\hline & 4 & -3.7748 & 2.36468 & .112 \\
\hline & 2 & $-4.3467^{*}$ & 1.78221 & .016 \\
\hline \multirow[t]{4}{*}{4} & 10 & $5.2337^{*}$ & 2.27813 & .023 \\
\hline & 8 & 3.6462 & 2.10230 & .084 \\
\hline & 6 & 3.7748 & 2.36468 & .112 \\
\hline & 2 & -.5719 & 2.15290 & .791 \\
\hline \multirow[t]{4}{*}{2} & 10 & $5.8056^{*}$ & 1.66567 & .001 \\
\hline & 8 & $4.2181^{*}$ & 1.41571 & .003 \\
\hline & 6 & $4.3467^{*}$ & 1.78221 & .016 \\
\hline & 4 & .5719 & 2.15290 & .791 \\
\hline
\end{tabular}

Based on Table 7 if the value sig. less than 0,05 then the null hypothesis was rejected. the null hypothesis states that there is a same average of learning habits of both samples. student learning habits $10^{\text {th }}$ semester equals $4^{\text {th }}$ semester students and $2^{\text {nd }}$ semester because the value of sig. 0.023 and 0.001 is less than 0.05 . student learning habits of the $2^{\text {nd }}$ semester equals to semester $6^{\text {th }}$ and semester $8^{\text {th }}$ due to the value of sig. 0,016 and 0.003 less than 0.05 , Through test of between-subject effects obtained adjusted $\mathrm{R}$ squared 0,45 means students' learning habits can be explained by gender and semesters are $45 \%$.

The first hypothesis tested in this study is whether there is a significant difference in the student learning habits of male and female students. The results of the analysis showed that there were no significant differences in the student learning habits of male and female students. its means that there is no impact of gender toward students mathematical learning habits. This result agree with the found of joseph that there is no significant difference in students' academic achievement in respect of gender (Joseph \& John, 2015). Based on the conclusion in the first hypothesis states that between men and women do not have significant different learning habits. How a person learns or how a person's learning habits will certainly be determined by the purpose of their learning. In other words, learning habits may different if a person has different motivations. Some studies have found that there are differences in learning habits reviewed from gender.

Other research results show different conclusions that males and females performance in mathematics are differentially affected by their study habits (Charles-Ogan, 2015), there is a

36 | $\begin{aligned} & \text { C2021 by Department of Mathematics Education, UMP, Purwokerto, Indonesia } \\ & \text { p-ISSN 2477-409X, e-ISSN: 2549-9084 and website: http://jurnal nasional.ump.ac.id/index.php/alphamath/ }\end{aligned}$ 
significant differences in the study habits of the students on the basis of age and gender. Study habits seem to improve with age and female students reported better study habits than males. This implies that proactive counselling against poor study habits should start at the basic level of education attention should be given to male students (Ossai, 2012). It is a limitation in ex post facto research where internal factor and external factors control of the respondent become a weakness. Internal control factors are controlling the factors in individual respondents that significantly affect students' learning habits. internal factors that can affect student learning habits are motivation and interest. External factors such as friends can influence student learning habits (Tahir et al., 2014).

The second hypothesis tested on this research is whether there are significant differences in student learning habits in each year class (semester). Based on the results of the analysis there are significant differences in student learning habits. This means that some semester has different learning habits from other semester. Then there is significant impact of year study class (semester) toward student learning habits. The results of this study are in accordance with the findings that age determines achievement including learning habit (Jabor et al., 2011; Siddiquah, 2019).Post hoc test indicated that students $10^{\text {th }}$ semester difference with student $4^{\text {th }}$ semester and $2^{\text {th }}$ semester. Students $2^{\text {th }}$ semester difference with $6^{\text {th }}$ semester and $8^{\text {th }}$ semester.

Year class determine the learning style and learning planning that will become a habit of learning (Khathri \& Daud, 2018). The differences in student learning habits are reviewed from the semester, due to age differences, attitudes as different age. age and gender are significant variables for difference students learning habit (Ossai, 2012).

\section{Conclusion}

The conclusion in this study is two-way Analysis of variance with variable gender and years class as independent variable and learning habits as dependent variable indicates that for variable gender sig. value 0,930 is more than 0,05 so that null hypothesis is accepted. Null hypothesis accepted means not differences students mathematical learning habits between men and women. in variables of semester sig. value 0,008 is less than 0,05 so than null hypothesis is Rejected. Null hypothesis rejected means there are differences students mathematical learning habits between students in term of student years class (semester). Students mathematical learning habit in term of interaction gender and semester have Sig. value 0,858 is more than 0,05 . It is means there are no interaction between gender and semester toward students mathematical learning habits.

\section{References}

Amuda, B. G., \& Ali, D. G. (2018). Relationship Among Study Habits, Gender, Marital Status, Age, Parents' Level Of Education And Academic Performance Of Nce Students In Kashim Ibrahim College Of Education Maiduguri, Borno State, Nigeria. 6(4), 78-89.

Charles-Ogan, G. (2015). Gender influences on study habits of mathematics students' achievement. International Journal of Academic Research and Reflection. Vol. 3, No. 7, ISSN 2309-0405, 3(7), 24-28.

Credé, M., \& Kuncel, N. R. (2008). Study Habits, Skills, and Attitudes: The Third Pillar Supporting Collegiate Academic Performance. Perspectives on Psychological Science, 3(6), 425-453. https://doi.org/10.1111/j.1745-6924.2008.00089.x

Ebele, U. F., \& Olofu, P. A. (2017). Study habit and its impact on secondary school students academic performance in biology in the Federal Capital Territory, Abuja. Educational Research and Reviews, 12(10), 583-588. https://doi.org/10.5897/err2016.3117

Jabor, M. K., Machtmes, K., Kungu, K., Buntat, Y., \& Nordin, M. S. (2011). The influence of age and 
JUNAIDI, AKHMAD ASYARI, ULFA LU'LUILMAKNUN, NILZA HUMAIRA SALSABILA, R Y TYANINGSIH

The Application Two-Way of Analysis Variance with Gender and Years Class

gender on the students ' achievement in mathematics. 2011 International Conference on Social Science and Humanity, 5, 304-308.

Joseph, A., \& John, O. (2015). Effect of Gender on Students' Academic Performance in Computer Studies in Secondary Schools in New Bussa, Borgu Local Government of Niger State. Journal of Education and Practice, 6(33), 1-7.

Julius, M., \& Evans, A. S. (2015). Study of the relationship between study habits and academic achievement of students: A case of Spicer Higher Secondary School, India. International Journal of Educational Administration and Policy Studies, 7(7), 134-141. https://doi.org/10.5897/ijeaps2015.0404

Khathri, A. M., \& Daud, C. H. R. (2018). Relationship between motivation, learning habit and overall results of polytechnic mechanical engineering student. Journal of Counseling and Educational Technology, 1(2), 41-49. https://doi.org/10.32698/0131

Ossai, M. C. (2012). Age and Gender Differences in Study Habits: a Framework for Proactive Counselling Against Low Academic Achievement. Journal of Educational and Social Research, 2(3), 67-73. https://doi.org/10.5901/jesr.2012.v2n3p67

Pamujo. (2014). The Effect of Self-Concept, Learning Habit, and Motive of Achievement toward the Learning Achievement. 7(August), 19-26.

Purwaningsih, D. (2018). The Influence Of Intensity And Habits Learning On Mathematical Critical Thinking Ability. Journal of Chemical Information and Modeling, 2(2), 115-121. https://doi.org/10.1017/CBO9781107415324.004

Rabia, M., Mubarak, N., Tallat, H., \& Nasir, W. (2017). A Study on Study Habits and Academic Performance of Students. International Journal of Asian Social Science, 7(10), 891-897. https://doi.org/10.18488/journal.1.2017.710.891.897

Siddiquah, A. (2019). Effect of Gender, Age, Grade Level, Subjects, and Family Income on the Locus of Control of Secondary School Students. SAGE Open, 9(1), 0-5. https://doi.org/10.1177/2158244018823429

Silverrajoo, P., \& Hassan, A. (2018). Relationship between Study Habits and Academic Achievement among Health Science Students. International Journal of Academic Research in Business and Social Sciences, 8(7), 763-780. https://doi.org/10.6007/ijarbss/v8-i7/4418

Tahir, A., Koki, A., \& Abdullahi, U. (2014). Gender differences in study habit skills of undergraduate students of yobe state university, damaturu, yobe state, nigeria. Knowledge Review Volume 31 No. $2,31(2), 1-5$.

Urh, M., \& Jereb, E. (2014). Learning Habits in Higher Education. Procedia - Social and Behavioral Sciences, 116(January 2015), 350-355. https://doi.org/10.1016/j.sbspro.2014.01.220 